\title{
Effect of pulmonary rehabilitation on oxidative stress in patients with pulmonary diseases
}

\author{
Masayuki Itoh, Kenji Nemoto, Takao Tsuji, Hiroyuki Nakamura, Kazutetsu Aoshiba
}

Department of Respiratory Medicine, Tokyo Medical University Ibaraki Medical Center, Ibaraki, Japan

Email: kaoshiba@tokyo-med.ac.jp

Received 12 August 2012; revised 14 September 2012; accepted 6 October 2012

\begin{abstract}
Exercise-training-based pulmonary rehabilitation has been confirmed to be effective in improving the activities of daily living (ADL) and relieving the dyspnea of chronic obstructive pulmonary disease (COPD) patients. Exercise training increases the antioxidant capacity of COPD patients, but since strenuous exercise and acute exercise loading have the opposite effect and increase oxidative stress, it is important to establish exercise training conditions that efficiently raise antioxidant capacity without increasing oxidative stress. Research on oxidative stress during exercise training by COPD patients has been pursued from that standpoint, but in recent years the targets of research on respirator diseases other than COPD have been expanding. In this article we will therefore review the results of research that has been conducted thus far on the effect of pulmonary rehabilitation on oxidative stress, including the results obtained at our own institution.
\end{abstract}

Keywords: Pulmonary Rehabilitation; Exercise; Oxidative Stress; Antioxidants; Chronic Obstructive Pulmonary Disease

\section{INTRODUCTION}

Pulmonary rehabilitation has been confirmed to be effective in improving the activities of daily living (ADL) of chronic obstructive pulmonary disease (COPD) patients and relieving their dyspnea [1]. Pulmonary rehabilitation centers on continuous exercise training, but in view of the possibility of continuing to perform it at home, walking exercise has become the most popular form of continuous exercise training. Exercise training increases the body's antioxidant capacity, but strenuous exercise or acute exercise loading have the opposite effect and instead increase oxidative stress [2]. Particularly since oxidative stress and nitrosative stress increase in COPD patients even at rest, COPD patients appear to develop severe oxidative stress even when the exercise load is mild [3].

\section{OXIDATIVE STRESS IN THE MUSCLES OF COPD PATIENTS}

As a result of the effects of decreased daily activities and of generalized inflammation and oxidative stress, the cross-sectional area of the quadriceps femoris muscle of COPD patients decreases, and there is a decrease in the number of type I fibers (slow-twitch fibers), which have endurance strength, and an increase in the proportion type IIb fibers (fast-twitch fibers), which fatigue easily [4]. Since other changes, including decreases in the numbers of capillaries and mitochondria, an increase in oxidative stress, and a decrease in energy production, occur in the muscles of COPD patients in addition to these quantitative and qualitative changes in muscle fibers [5-13], the muscles of healthy subjects and COPD patients respond differently even when they perform same exercise training. Actually, differences are known to occur in the level of gene expression in muscle exercise training by healthy subjects and COPD patients. For example, increases in oxidative stress and in the level of expression of ubiquitin-proteasome pathway genes and cytochrome c oxidase assembly (COX)-11, COX15, and mitogen-activated protein kinase (MAPK)-9 genes have been reported in the quadriceps femoris of COPD patients who performed exercise training for 3 months when compared with healthy subjects [14]. These changes seem to be results that reflect the effects of cellular stress, including hypoxia, but they are effects that should be taken into consideration in order to conduct exercise training in COPD patients effectively and safely. In addition, a higher degree of protein carbonylation and myosin heavy chain oxidation appears in the quadriceps femoris muscle of COPD patients after exercise training than in healthy subjects, and the protein levels of the antioxidant enzymes manganese-superoxide dismutase (Mn-SOD) and copper/zinc-superoxide dismutase (Cu/Zn-SOD) increased [15]. Furthermore, increases in oxidative stress and nitrosative stress accompanied by an increase in total 
SOD activity have been observed in the muscles of COPD patients while they are at rest [16]. Based on the above results, oxidative stress appears to increase in the skeletal muscles of COPD patients during exercise and at rest.

\section{EXERCISE LOAD AND OXIDATIVE STRESS IN COPD PATIENTS}

Changes in inflammatory markers and oxidative stress have often been measured as indicators of the effect of exercise loading on COPD patients (Table 1). Since there are systemic increases in the inflammatory response and oxidative stress in COPD patients even while they are at rest [17], it has been pointed out that acute exercise loading, even if it is local exercise of the lower limbs, may aggravate the systemic inflammation and oxidative stress of COPD patients [18]. Moreover, results have even been published showing that the oxidative stress of COPD patients who had developed muscle fatigue increased as a result of only mild exercise loading, such as in the 6-minute walk test (6MWT), which is a common test [19]. When we summarized the effects of acute exercise loading on COPD patients thus far (Table 1), we found that many reports pointed to decreased antioxidant capacity and increases in lipid peroxides (thiobarbituric acid reactive substances [TBARS] and malondialdehyde [MDA]) and protein carbonyls (PC) [18-29], although some studies showed no changes in the levels of oxidative stress markers [30-32]. And if viewed as a whole, they were results that supported increased oxidative stress in whole body and muscles as a result of acute exercise loading. On the other hand, there are research results showing that, in contrast to healthy subjects, no increases in reactive nuclear factor (NF)- $\kappa \mathrm{B}$ activation, interleukin-1beta (IL-1 $\beta$ ) production, antioxidant proteins (thioredoxin [TRX], Mn-SOD, heme oxygenase1 [HO-1]), or stress-protective proteins (heat shock protein-70 [HSP-70]) occurred in the quadriceps femoris muscle when COPD patients engaged in acute exercise loading [32]. Because, based on these research findings, the inflammatory response in the muscles of COPD patients as a result of acute exercise loading decreases, it is understood to be a situation in which up-regulation of the defense system tends not to occur.

There is also a report that the concentration of mitochondrial DNA in the vastus lateralis muscle of COPD patients decreased when they performed high-intensity acute exercise that exceeded the lactate threshold (LT) [33]. The mitochondrial DNA concentration in the skeletal muscles of healthy subjects also decreases if they perform intense exercise, but because the gene that encodes peroxisome proliferators-activated receptor-coactivator- $1 \alpha$ (PGC- $1 \alpha)$, which is involved in mitochondrial energy production during high-intensity exercise, is over- expressed in COPD patients, excessive production of active oxygen species as a result of intense exercise may be the reason for the decrease in mitochondrial DNA [33]. Based on these research findings, pulmonary rehabilitation exercise whose intensity does not exceed the LT is recommended for COPD patients.

Summarizing the above research findings, there is a strong possibility of oxidative stress in the muscles and blood of COPD patients increasing during acute exercise. Thus, pulmonary rehabilitation programs that avoid overtraining appear to be desirable in order to keep the increase in oxidative stress to a minimum and to efficiently induce antioxidant capacity during the pulmonary rehabilitation of COPD patients.

\section{ADAPTIVE RESPONSE TO OXIDATIVE STRESS DURING EXERCISE TRAINING}

Exercise training does not usually improve the respiratory function of COPD patients, but it does increase their exercise tolerance. The possibility of activation of the stress adaptation response being the mechanism responsible for the increase in exercise tolerance as a result of exercise training has attracted interest. For example, accumulation of ammonia in the skeletal muscles of COPD patients is the cause of their muscle fatigue, but because less mitochondrial adenosine triphosphate (ATP) was produced than was needed, the ammonia accumulation appeared to have resulted from an increase in the catabolism of adenine nucleotides [34]. However, it has been reported that an adaptive response occurs in skeletal muscle when exercise training is performed, and the increase in ammonia is suppressed [35]. Other examples of adaptive responses as a result of exercise training in addition to this have been reported, including recovery of the muscle mass of skeletal muscles and from muscle composition changes and mitochondrial activation [3639], but few studies have investigated the long-term effects of exercise training (Table 2).

However, very interesting research findings, including prevention of the onset of COPD and suppression of oxidative stress, have begun to be reported recently as adaptive responses due to long-term exercise training. For example, it has been demonstrated that smokers who routinely engage in moderate to high-intensity exercise tend not to develop COPD [40]. On the other hand, when Toledo et al. repeatedly subjected rats to aerobic exercise for a 24-week period, they observed that the increase in 8 -isoprostane as a result of smoking and decreases in interleukin-10 (IL-10), tissue inhibitor of metalloproteinase (TIMP)-1, and $\mathrm{Cu} / \mathrm{Zn}$-SOD were inhibited [41]. Pinho et al. observed that even when COPD patients who had completed 8 weeks of pulmonary rehabilitation engaged in acute exercise loading, their xanthine oxidase 
Table 1. Effects of acute exercise on oxidative stress in COPD patients.

\begin{tabular}{|c|c|c|c|c|c|}
\hline Authors & Exercise type & Subjects & Sample & Sampling time & Effects \\
\hline Vina, $1996[20]$ & Cycle ergometry until exhaustion & 9 COPD patients & Blood & Pre, post & $\mathrm{GSH} / \mathrm{GSSG} \uparrow$ \\
\hline $\begin{array}{c}\text { Heunks, } 1999 \\
{[21]}\end{array}$ & Cycle ergometry until exhaustion & 8 severe COPD patients & Blood & Pre, post $(0,1 \mathrm{~h})$ & $\begin{array}{c}\mathrm{GSH} / \mathrm{GSSG} \uparrow(0,1 \mathrm{~h}) \\
\mathrm{MDA} \uparrow\end{array}$ \\
\hline $\begin{array}{c}\text { Couillard, } 2002 \\
{[18]}\end{array}$ & Knee extensions until exhaustion & $\begin{array}{l}11 \text { moderate to severe COPD } \\
\text { patients }\end{array}$ & Blood & Pre, post (6 h) & TBARS $\uparrow$ \\
\hline $\begin{array}{c}\text { Couillard, } 2003 \\
{[22]}\end{array}$ & Knee extensions until exhaustion & 10 severe COPD patients & Muscle & Pre, post (48 h) & $\mathrm{TBARS} \uparrow, \mathrm{PC} \uparrow$ \\
\hline $\begin{array}{l}\text { Agacdiken, } 2004 \\
{[23]}\end{array}$ & $\begin{array}{l}\text { Treadmill exercise test until } \\
\text { exhaustion }\end{array}$ & 21 COPD patients & Blood & Pre, post $(1,3 \mathrm{~h})$ & $\mathrm{MDA} \uparrow(3 \mathrm{~h}), \mathrm{GSH} \rightarrow$ \\
\hline $\begin{array}{l}\text { Koechlin, } 2004 \\
{[24]}\end{array}$ & Knee extensions until exhaustion & $\begin{array}{l}10 \text { moderate to severe COPD } \\
\text { patients }\end{array}$ & Blood & $\begin{array}{l}\text { Pre, post }(0,6 \\
\quad 24,48 \mathrm{~h})\end{array}$ & $\begin{array}{c}\operatorname{TBARS} \uparrow(0,6 \mathrm{~h}), \mathrm{PC} \uparrow \\
(6 \mathrm{~h})\end{array}$ \\
\hline \multirow[t]{2}{*}{$\begin{array}{c}\text { Koechlin, } 2004 \\
{[25]}\end{array}$} & Knee extensions until exhaustion & 9 severe COPD patients & Blood & Pre, post $(0,6 \mathrm{~h})$ & TBARS $\uparrow(0,6 \mathrm{~h})$ \\
\hline & & & & & $\mathrm{PC} \uparrow(6 \mathrm{~h})$ \\
\hline \multirow[t]{3}{*}{$\begin{array}{l}\text { Mercken, } 2005 \\
{[26]}\end{array}$} & $\begin{array}{l}\text { Maximal and submaximal ( } 60 \% \text { of } \\
\text { peak work load) cycle ergometry }\end{array}$ & $\begin{array}{l}11 \text { moderate to very severe COPD } \\
\text { patients }\end{array}$ & Urine & Pre, post $(0,4 \mathrm{~h})$ & $\begin{array}{l}\text { MDA } \uparrow(\max , 0,4 \mathrm{~h} ; \\
\quad \text { submax, } 4 \mathrm{~h})\end{array}$ \\
\hline & & & Breath & & $\mathrm{H}_{2} \mathrm{O}_{2} \uparrow(\max , 4 \mathrm{~h})$ \\
\hline & & & Blood & & DNA damage $\uparrow(4 \mathrm{~h})$ \\
\hline \multirow[t]{3}{*}{$\begin{array}{l}\text { Van Helvoort, } \\
2006[27]\end{array}$} & $\begin{array}{l}\text { Maximal and submaximal ( } 50 \% \text { of } \\
\text { maximal work rate) cycle ergometry }\end{array}$ & 20 muscle-wasted COPD patients & Blood & Pre, post & $\mathrm{PC} \rightarrow$ \\
\hline & & & & & TBARS $\uparrow$ \\
\hline & & & & & GSH/GSSG $\uparrow$ \\
\hline \multirow[t]{2}{*}{$\begin{array}{l}\text { Van Helvoort, } \\
2007[19]\end{array}$} & 6-minute walk test & $\begin{array}{l}10 \text { patients with muscle-wasted } \\
\text { COPD }\end{array}$ & Blood & Pre, post & TBARS $\uparrow$ \\
\hline & & & & & $\mathrm{PC} \uparrow$ \\
\hline \multirow[t]{3}{*}{ Pinho, 2007 [30] } & $\begin{array}{l}60 \% \text { of maximal load in an } \\
\text { incremental }\end{array}$ & $\begin{array}{c}7 \text { moderate to severe COPD } \\
\text { patients }\end{array}$ & Blood & Pre, post & TBARS $\rightarrow$ \\
\hline & cycle ergometry & & & & TRAP $\rightarrow$ \\
\hline & & & & & $\mathrm{XO} \downarrow$ \\
\hline $\begin{array}{c}\text { Jammes, } 2008 \\
{[28]}\end{array}$ & Cycle ergometry until exhaustion & 17 hypoxemic COPD patients & Blood & $\begin{array}{l}\text { Pre, post }(5,10 \\
\quad 20,30 \mathrm{~min})\end{array}$ & TBARS $\uparrow(5,10 \mathrm{~min})$ \\
\hline \multirow[t]{3}{*}{$\begin{array}{c}\text { Mercken, } 2009 \\
{[31]}\end{array}$} & Cycle ergometry until exhaustion & 9 moderate COPD patients & Urine & Pre, post (2 h) & $\mathrm{MDA} \rightarrow(2 \mathrm{~h})$ \\
\hline & & & Erythrocytes & & $\mathrm{GSH} / \mathrm{GSSG} \rightarrow(2 \mathrm{~h})$ \\
\hline & & & & & SOD activity $\rightarrow(2 \mathrm{~h})$ \\
\hline \multirow[t]{3}{*}{$\begin{array}{l}\text { Mercken, } 2009 \\
{[29]}\end{array}$} & Submaximal single-leg ergometry & $\begin{array}{l}15 \text { moderate to severe COPD } \\
\text { patients }\end{array}$ & Urine & Pre, post $(0,2 \mathrm{~h})$ & $\operatorname{MDA} \uparrow(0 \mathrm{~h})$ \\
\hline & & & Erythrocytes & & $\mathrm{GSH} / \mathrm{GSSG} \uparrow(0 \mathrm{~h})$ \\
\hline & & & $\begin{array}{l}\text { Breath } \\
\text { condensate }\end{array}$ & & $\mathrm{H}_{2} \mathrm{O}_{2} \uparrow(0,2 \mathrm{~h})$ \\
\hline \multirow[t]{3}{*}{$\begin{array}{l}\text { Mercken, } \\
2011[32]\end{array}$} & Submaximal cycle ergometry & 7 patients with moderate COPD & Muscle & Pre, post $(0,2 \mathrm{~h})$ & $\begin{array}{l}\text { Mn-SOD mRNA } \rightarrow \\
\quad(0,2 \mathrm{~h})\end{array}$ \\
\hline & & & & & TRX mRNA $\rightarrow(0,2 \mathrm{~h})$ \\
\hline & & & & & $\mathrm{PC} \rightarrow(0,2 \mathrm{~h})$ \\
\hline
\end{tabular}

Abbreviations: GSH, glutathione-SH; GSSG, GSSG, glutathione-S-S-glutathione; MDA, malondialdehyde; TBARS, thiobarbituric acid reactive substances; PC, protein carbonyls; TRAP, total radical-trapping antioxidant parameter; SOD, superoxide dismutase, TRX; thioredoxin. 
Table 2. Effects of exercise training and pulmonary rehabilitation on oxidative stress in COPD patients.

\begin{tabular}{|c|c|c|c|c|c|}
\hline Authors & Exercise type & Subjects & Sample & Sampling time & Effects \\
\hline \multirow[t]{5}{*}{$\begin{array}{l}\text { Mercken, } \\
2005(26)\end{array}$} & $\begin{array}{l}\text { Maximal and submaximal }(60 \% \\
\text { work load) cycle ergometry } \\
\text { before and after } 8 \text { wk of } \\
\text { rehabilitation program }\end{array}$ & $\begin{array}{l}11 \text { moderate to severe COPD } \\
\text { patients }\end{array}$ & Urine & Pre, post $(0,4 \mathrm{~h})$ & $\begin{array}{l}\text { MDA } \uparrow(\max , 4 \mathrm{~h} ; \\
\quad \text { submax, } 0 \mathrm{~h})\end{array}$ \\
\hline & & & Breath condensate & & $\begin{array}{l}\mathrm{H}_{2} \mathrm{O}_{2} \uparrow(\max , 4 \mathrm{~h}) \text { or } \rightarrow \\
\quad(\text { submax }, 0,4 \mathrm{~h})\end{array}$ \\
\hline & & & Blood & & $\begin{array}{l}\text { Uric acid } \uparrow(\max , 0,4 \mathrm{~h}) \\
\text { or } \rightarrow(\text { submax, } 0,4 \mathrm{~h})\end{array}$ \\
\hline & & & Mononuclear cells & & $\begin{array}{c}\text { ROS-induced DNA } \\
\text { damage } \downarrow\end{array}$ \\
\hline & & & & & (submax, $4 \mathrm{~h}$ ) \\
\hline \multirow[t]{4}{*}{$\begin{array}{l}\text { Rabinovich, } \\
2006(45)\end{array}$} & $\begin{array}{l}8 \text { wk of high-intensity } \\
\text { endurance training }\end{array}$ & $\begin{array}{l}11 \text { normal BMI COPD } \\
\text { patients, } 9 \text { low BMI COPD } \\
\text { patients }\end{array}$ & Muscle & Pre, post & Low BMI: GSH $\downarrow$ \\
\hline & (cycle ergometry) & & & & Normal BMI: GSH $\rightarrow$ \\
\hline & & & & & Low and normal BMI: \\
\hline & & & & & Lipid peroxidation $\rightarrow$ \\
\hline \multirow[t]{4}{*}{$\begin{array}{l}\text { Pinho, } 2007 \\
\quad(30)\end{array}$} & $\begin{array}{l}60 \% \text { of maximal load in an } \\
\text { incremental cycle ergometry }\end{array}$ & $\begin{array}{c}8 \text { moderate to severe COPD } \\
\text { patients }\end{array}$ & Blood & Pre, post & TBARS $\rightarrow$ \\
\hline & $\begin{array}{c}\text { after } 8 \text { wk of rehabilitation } \\
\text { program (1 h a session, } 3 \text { times a } \\
\text { week })\end{array}$ & & & & \\
\hline & & & & & TRAP $\rightarrow$ \\
\hline & & & & & XO activity $\downarrow$ \\
\hline \multirow[t]{3}{*}{$\begin{array}{l}\text { Barreiro, } \\
2009(42)\end{array}$} & $\begin{array}{l}3 \mathrm{wk} \text { of endurance training (cycle } \\
\text { ergometry, } 1 \mathrm{~h} \text { a session, } 5 \text { days a } \\
\text { week) }\end{array}$ & 15 severe COPD patients & Muscle & Pre, post & Total SOD activity $\rightarrow$ \\
\hline & & & & & $\mathrm{PC} \rightarrow$ \\
\hline & & & & & HNE-protein $\uparrow$ \\
\hline \multirow[t]{2}{*}{$\begin{array}{l}\text { Nemoto } 2012 \\
\quad(50)\end{array}$} & $\begin{array}{l}8 \mathrm{wk} \text { of high-intensity endurance } \\
\text { training }\end{array}$ & $\begin{array}{l}12 \text { moderate to severe COPD } \\
\text { patients }\end{array}$ & Blood & Pre, post & TBARS $\downarrow$ \\
\hline & $\begin{array}{l}\text { [conditioning and lower limbs } \\
\text { muscle training }(20 \text { min } \times 2 \text { sets }) \\
5 \text { days a week and walking exer- } \\
\text { cise every day] }\end{array}$ & & & & Nitrotyrosin $\rightarrow$ \\
\hline \multirow[t]{7}{*}{$\begin{array}{l}\text { Rodriguez, } \\
2012(16)\end{array}$} & $\begin{array}{l}8 \mathrm{wk} \text { of high-intensity endurance } \\
\text { training }\end{array}$ & 18 severe COPD patients & Blood & Pre, post & $\begin{array}{l}\mathrm{MDA} \rightarrow \\
\mathrm{GSH} \rightarrow \\
\mathrm{PC} \rightarrow\end{array}$ \\
\hline & $\begin{array}{l}\text { (cycle ergometry, } 1 \mathrm{~h} \text { a session, } \\
5 \text { days a week,) }\end{array}$ & & & & \\
\hline & & & Muscle & & $\begin{array}{l}\text { GSH } \rightarrow \\
\text { SOD content } \rightarrow\end{array}$ \\
\hline & & & & & Total SOD activity $\rightarrow$ \\
\hline & & & & & CAT content $\rightarrow$ \\
\hline & & & & & CAT activity $\rightarrow \mathrm{PC} \rightarrow$ \\
\hline & & & & & Protein nitration $\downarrow$ \\
\hline
\end{tabular}

Abbreviations: MDA, malondialdehyde; ROS, reactive oxygen species; BMI, body mass index; TBARS, thiobarbituric acid reactive substances; XO, xanthine oxidase; SOD, superoxide dismutase; PC, protein carbonyls; HNE, 4-hydroxynonenal; GSH, glutathione-SH; CAT, catalase. 
(XO) activity did not increase and blood lipid peroxide (TBARS) levels decreased, and they concluded that long-term pulmonary rehabilitation reduced exerciseinduced oxidative stress [29]. In addition, Mercken et al. demonstrated that after COPD patients had completed pulmonary rehabilitation and then engaged in acute exercise loading, the amount of lipid peroxides in their urine, amount of hydrogen peroxide in their exhaled breath condensate, and amounts of uric acid and oxidative DNA damage in their plasma had decreased compared to COPD patients who engaged in acute exercise loading without preceding pulmonary rehabilitation [26]. Similarly, Rodriguez et al. reported that nitrosative stress in patients with severe COPD had decreased after they completed an 8-week period of high-intensity exercise training [16]. Based on the above results, long-term continuous exercise training appears to activate an adaptive response to oxidative stress. Nevertheless, there are also research results showing that endurance exercise increases nitrosative stress in severe COPD without affecting antioxidant enzyme activity [42]. However, doubt persists as to whether the intensity of the exercise performed in that study (pedaling a bicycle ergometer for 1 hour a day) or the duration of the exercise (5 days a week for 3 weeks) was appropriate as adequate endurance exercise. For example, in an animal experiment conducted on mice that compared the effectiveness of exercise training for 4 weeks and for 8 weeks, increases in the activity of succinate dehydrogenase (SDH) and mitochondrial respiratory chain complexes 1, 2, 3 and 4 and decreases in TBARS and PC were finally observed at 8 weeks [43]. Based on the results of this animal experiment it is concluded that a longer period of training is necessary in order to induce an adaptive response to oxidative stress.

Continuing exercise for 20 minutes or more a session, 3 or more times a week, for 6 to 8 weeks or more is recommended to increase the efficacy of exercise training clinically, and high-intensity exercise at $60 \%-80 \%$ peak $\mathrm{VO}_{2}$ is said to be highly effective [44]. However, a greater decrease in the amount of reduced glutathione (GSH) in the vastus lateralis muscle after 8 weeks of high-intensity exercise training was reported in a group of COPD patients with a low body mass index (BMI) than in a group with a normal BMI [45]. Thus, COPD patients who have a smaller muscle mass may be more susceptible to the effects of oxidative stress as a result of exercise.

Oxidative stress during exercise is also affected by hypoxic states [46]. For example, negative correlations have been found between the blood TBARS, IL-6, and tumor necrosis factor (TNF)- $\alpha$ concentrations of COPD patients and their $\mathrm{PaO}_{2}$ values [28]. Moreover, oxidative stress, including TBARS, PC, and XO activity, was found to decrease in COPD patients who exercised while inhaling oxygen $(4 \mathrm{~L} / \mathrm{min})$ in comparison with patients who did not inhale oxygen [47], and results showing that oxidation of GSH was suppressed by oxygen administration have also been published [20]. Thus, treatment of hypoxemia is also necessary to prevent increases in oxidative stress while performing exercise training.

\section{SIGNIFICANCE OF SOD MEASUREMENTS DURING EXERCISE TRAINING BY COPD PATIENTS}

As shown above, appropriate exercise training by COPD patients may activate an adaptive response to oxidative stress and increase the body's antioxidant capacity. We therefore thought that measurements of serum SOD content might serve as a biomarker for judging tvvhe efficacy of exercise training, and we investigated whether it would.

SOD is an antioxidant enzyme that is positioned at the top of the antioxidant system in the body, but three different isozymes are known to exist according to the location, and one of the isozymes, manganese-superoxide dismutase (Mn-SOD), is present in mitochondria [48]. We conducted a pulmonary rehabilitation program that consisted of breathing exercises, upper and lower limb muscle strength training, and walking training for 8 weeks in 10 COPD patients. Before and after the rehabilitation program we had them perform the $6 \mathrm{MWT}$ as an indicator of exercise tolerance, and we measured their serum Mn-SOD content as an indicator of antioxidant capacity and their serum TBARS concentration as an indicator of lipid peroxidation. We calculated peak $\mathrm{VO}_{2}$ from the 6MWT prediction formula, and set the intensity of the walking training at $60 \%-70 \%$ of the value obtained. The results of the comparison between before and after the pulmonary rehabilitation program showed no changes in respiratory function, but the distance walked (6MWT) improved (Figure 1(a)), and a decrease in serum TBARS and increase in serum Mn-SOD content were observed after the pulmonary rehabilitation program (Figures 1(b) and (c)). Based on these results, we concluded that the pulmonary rehabilitation program increased antioxidant capacity without increasing oxidative stress, and the results showed that serum Mn-SOD content measurements might be useful in judging the efficacy of exercise training [49,50].

\section{EFFICACY OF ANTIOXIDANTS AGAINST OXIDATIVE STRESS DURING EXCERCISE}

Attempts have also been made to reduce oxidative stress during exercise by administering antioxidants to COPD patients. For example, there are results of a study show- 


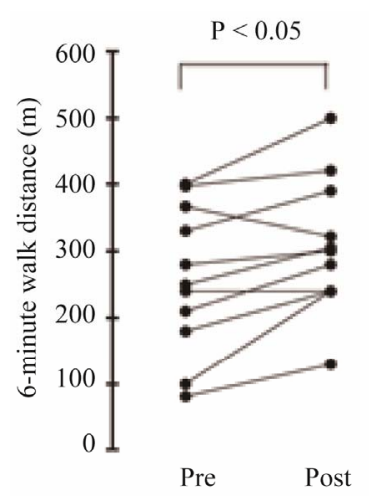

(a)

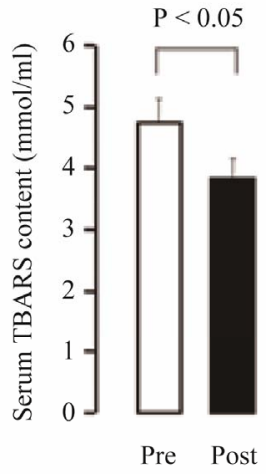

(b)

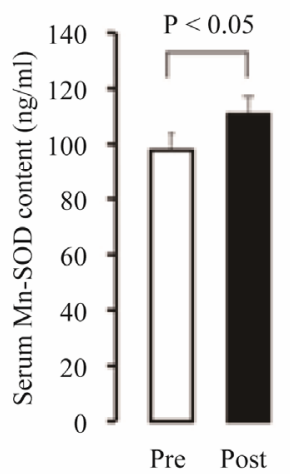

(c)

Figure 1. Effects of pulmonary rehabilitation on 6MWT (a), serum TBARS content (b), and serum MnSOD content $(\mathrm{c})$ in COPD patients $(\mathrm{n}=10)$. Data in $(\mathrm{b})$ and (c) are presented as means \pm SEM. ${ }^{*} \mathrm{P}<0.05$ vs. pre-rehabilitation.

ing that increases in lipid peroxides in the blood of COPD patients given vitamin $\mathrm{C}$ or vitamin $\mathrm{E}$ were prevented and their exercise tolerance improved [23], and results have been published showing that intravenous infusion of dichloroacetate (DCA), which is used to treat lactic acidosis, prevented increases in urinary uric acid values (an indirect indicator of oxidative stress) during exercise [31]. There is also a report that when the XO inhibitor allopurinol was given to COPD patients orally no increase in lipid peroxides or decrease in GSH was observed in their blood during exercise [21]. Based on these findings XO appears to be important as a source of production of active oxygen species during exercise. Results showing that administration of $\mathrm{N}$-acetylcysteine (NAC) reduced the oxidative stress of COPD patients and improved their exercise tolerance have also been presented [25].

\section{EXERCISE TRAINING FOR OTHER RESPIRATORY DISEASES AND OXIDATIVE STRESS}

In regard to other respiratory diseases besides COPD, the relationship between exercise training and oxidative stress has been investigated in bronchial asthma [51]. When children with bronchial asthma in that study were divided into a group treated with routine drug therapy that included inhaled steroids and a group treated with drug therapy + exercise training, blood SOD activity was found to increase in both groups, but an improvement in respiratory function, increase in glutathione peroxidase (GPX) activity, and a decrease in lipid peroxides were observed in the drug therapy + exercise training group alone. Based on these research findings it appears that, by increasing antioxidant capacity, exercise training may exert a therapeutic effect that is additive to drug therapy for asthma.

Evaluations of the efficacy of pulmonary rehabilitation in idiopathic pulmonary fibrosis (IPF) have been inconsistent [52,53], and increases in urinary 8-isoprostane and decreases in total antioxidant capacity (TAC) have been observed after exercise loading by low-intensity bicycle ergometer exercise [54]. However, it is unknown whether antioxidant capacity is induced by continuous exercise training.

\section{CONCLUSION}

Differences in the intensity of the exercise, duration of the exercise, and exercise methods have greatly influenced the results of research on pulmonary rehabilitation and exercise training. Differences in the severity of the subjects' disease, their body weight, and muscle mass, whether or not they are hypoxemic, and differences in the classes of drugs used to treat them (theophylline, steroids, etc.), and the periods when the specimens were collected are also important variables that have affected the results. Because of such variables the results of research on pulmonary rehabilitation and exercise training have not been consistent. However, continued research in regard to the establishment of exercise training conditions is necessary in order to increase antioxidant capacity while minimizing increases in oxidative stress, and to conduct pulmonary rehabilitation that is both safe and efficient.

\section{REFERENCES}

[1] Nici, L., Donner, C., Wouters, E., Zuwallack, R., Ambrosino, N. and Borbeau, J. (2006) AmericanThoracic Society/European Respiratory Society statement on pulmonary rehabilitation. American Journal of Respiratory and Critical Care Medicine, 173, 1390-1413. doi:10.1164/rccm.200508-1211ST

[2] Oh-Ishi, S., Kizaki, T., Ookawara, T., Sakurai, T., Izawa, T. and Nagata, N. (1997) Endueance training improves the resistance of rat diaphragm to exercise induced oxidative stress. European Respiratory Journal, 156, 15791585 .

[3] Rahman, I. and Adcock, I.M. (2006) Oxidative stress and 
redox regulation of lung inflammation in COPD. European Respiratory Journal, 28, 219-242. doi:10.1183/09031936.06.00053805

[4] Caron, M., Debigaré, R., Dekhuijzen, P.N.R. and Maltais, F. (2009) Comparative assessment of the quadriceps and the diaphragm in patients with COPD. Journal of Applied Physiology, 107, 952-961. doi:10.1152/japplphysiol.00194.2009

[5] Whittom, F., Jobin, J., Simard, P.M., Leblanc, P., Simard, C. and Bernard, S. (1998) Histochemical and morphological characteristics of the vastus lateralis muscle in patients with chronic obstructive pulmonary disease. Medicine and Science in Sports and Exercise, 30, 1467-1474. doi:10.1097/00005768-199810000-00001

[6] Gosker, H.R., Zeegers, M.P., Wouters, E.F. and Schols, A.M. (2007) Muscle fiber type shifting in the vastus lateralis of patients with COPD is associated with disease severity: A systematic review and meta-analysis. Thorax, 62, 944-949. doi:10.1136/thx.2007.078980

[7] Jobin, J., Maltais, F., Doyon, J.F., LeBlanc, P., Simard, P.M. and Simard, A.A. (1998) Chronic obstructive pulmonary disease: Capillarity and fiber type characteristics of skeletal muscle. Journal of Cardiopulmonary Rehabilitation, 18, 432-437. doi:10.1097/00008483-199811000-00005

[8] Gosker, H.R., Hesselink, M.K., Duimel, H., Ward, K.A. and Schols, A.M. (2007) Reduced mitochondrial density in the vastus lateralis muscle of patients with COPD. European Respiratory Journal, 30, 73-79. doi:10.1183/09031936.00146906

[9] Picard, M., Godin, R., Sinnreich, M., Baril, J., Bourbeau, J. and Perrault, H. (2008) The mitochondrial phenotype of peripheral muscle in chronic obstructive pulmonary disease: Disuse or dysfunction? American Journal of Respiratory and Critical Care Medicine, 178, 1040-1047. doi:10.1164/rccm.200807-1005OC

[10] Puente-Maestu, L., Pérez-Parra, J., Godoy, R., Moreno, N., Tejedor, A. and González-Aragoneses, F. (2009) Abnormal mitochondrial function in locomotor and respiratory muscle of COPD patients. European Respiratory Journal, 33, 1045-1052. doi:10.1183/09031936.00112408

[11] Green, H.J., Bombardier, E. Burnett, M., Iqbal, S., D'Arsigny, C.L. and O'Donnell, D.E. (2008) Organization of metabolic pathways in vastus lateralis of patients with chronic obstructive pulmonary disease. American Journal of Physiology-Regulatory, Integrative and Comparative Physiology, 295, R935-R941. doi:10.1152/ajpregu.00167.2008

[12] Maltais, F., Le Blane, P., Whittom, F., Simard, C., Marquis, K. and Bélanger, M. (2000) Oxidative enzyme activities of the vastus lateralis muscle and the functional status in patients with COPD. Thorax, 55, 848-853. doi:10.1136/thorax.55.10.848

[13] Maltais, F., Simard, A.A., Simard, C., Jobin, J., Desgagnés, P. and LeBlanc, P. (1996) Oxidative capacity of the skeletal muscle and lactic acid kinetics during exercise in normal subjects and in patients with COPD. American Journal of Respiratory and Critical Care Medicine, 153, 288-293.
[14] Radom-Aizik, S., Kaminski, N. Hayek, S., Halkin, H., Cooper, D.M. and Ben-Dov, I. (2007) Effects of exercise training on quadriceps muscle gene expression in chronic obstructive pulmonary disease. Journal of Applied Physiology, 102, 1976-1984.

doi:10.1152/japplphysiol.00577.2006

[15] Fermoselle, C., Rabinovich, R. Ausín, P., Puig-Vilanova, E., Coronell, C. and Sanchez, F. (2012) Does oxidative stress modulate limb muscle atrophy in severe COPD patients? European Respiratory Journal, 40, 851-862.

[16] Rodriguez, D.A., Kalko, S., Puig-Vilanova, E., PerezOlabarría, M., Falciani, F. and Gea, J. (2012) Muscle and blood redox status after exercise training in severe COPD patients. Free Radical Biology \& Medicine, 52, 88-94. doi:10.1016/j.freeradbiomed.2011.09.022

[17] Macnee, W. (2001) Oxidative stress and lung inflamemation in airways disease. European Journal of Pharmacology, 429, 195-207. doi:10.1016/S0014-2999(01)01320-6

[18] Couillard, A., Koechlin, C. Cristol, J.P., Varray, A. and Prefaut, C. (2002) Evidence of local exercise-induced systemic oxidative stress in chronic obstructive pulmonary disease patients. European Respiratory Journal, 20, 1123-1129. doi:10.1183/09031936.02.00014302

[19] van Helvoort, H.A., Heijdra, Y.F., de Boer, R.C., Swinkels, A., Thijs, H.M. and Dekhuijzen, P.N. (2007) Sixminutes walking-induced systemic inflammation and oxidative stress in muscle-wasted COPD patient. Chest, 131, 439-445. doi:10.1378/chest.06-1655

[20] Viña, J., Servera, E., Asensi, M., Sastre, J., Pallardó, F.V. and Ferrero, J.A. (1996) Exercise causes blood glutathione oxidation in chronic obstructive pulmonary disease: Prevention by $\mathrm{O}_{2}$ therapy. Journal of Applied Physiology, 81, 2198-2202.

[21] Heunks, L.M., Viña, J. van Herwaarden, C.L., Folgering, H.T., Gimeno, A. and Dekhuijzen, P.N. (1999) Xanthine oxidase is involved in exercise-induced oxidative stress in chronic obstructive pulmonary disease. American Journal of Physiology, 277, R1697-R1704.

[22] Couillard, A., Maltais, F., Saey, D., Debigaré, R., Michaud, A. and Koechlin, C. (2003) Exercise-induced quadriceps oxidative stress and peripheral muscle dysfunction in patients with chronic obstructive pulmonary disease. American Journal of Respiratory and Critical Care Medicine, 167, 1664-1669. doi:10.1164/rccm.200209-10280C

[23] Agacdiken, A., Basyigit, I., Ozden, M., Yildiz, F., Ural, D. and Maral, H. (2004) The effects of antioxidants on exercise-induced lipid peroxidation in patients with COPD. Respirology, 9, 38-42. doi:10.1111/j.1440-1843.2003.00526.x

[24] Koechlin, C., Couillard, A., Cristol, J.P., Chanez, P., Hayot, M. and Le Gallais, D. (2004) Does systemic inflamemation trigger local exercise-induced oxidative stress in COPD? European Respiratory Journal, 23, 538-544. doi:10.1183/09031936.04.00069004

[25] Koechlin, C., Couillard, A., Simar, D., Cristol, J.P., Bellet, H. and Hayot, M. (2004) Does oxidative stress alter quadricceps endurance in chronic obstructive pulmonary 
disease? American Journal of Respiratory and Critical Care Medicine, 169, 1022-1027. doi:10.1164/rccm.200310-1465OC

[26] Mercken, E.M., Hageman, G.J., Schols, A.M., Akkermans, M.A., Bast, A. and Wouters, E.F. (2005) Rehabilitation decreases exercise-induced oxidative stress in chronic obstructive pulmonary disease. American Journal of Respiratory and Critical Care Medicine, 172, 994-1001. doi:10.1164/rccm.200411-1580OC

[27] van Helvoort, H.A., Heijdra, Y.F., Thijs, H.M., Viña, J., Wanten, G.J. and Dekhuijzen, P.N. (2006) Exercise-induced systemic effects in muscle-wasted patients with COPD. Medicine and Science in Sports and Exercise, 38, 1543-1552. doi:10.1249/01.mss.0000228331.13123.53

[28] Jammes, Y., Steinberg, J.G., Ba, A., Delliaux, S. and Brégeon, F. (2008) Enhanced exercise-induced plasma cytokine response and oxidative stress in COPD patients depend on blood oxygenation. Clinical Physiology and Functional Imaging, 28, 182-188. doi:10.1111/j.1475-097X.2008.00795.x

[29] Mercken, E.M., Gosker, H.R., Rutten, E.P., Wouters, E.F., Bast, A. and Hageman, G.J. (2009) Systemic and pulmonary oxidative stress after single-leg exercise in COPD. Chest, 136, 1291-1300. doi:10.1378/chest.08-2767

[30] Pinho, R.A., Chiesa, D., Mezzomo, K.M., Andrades, M.E., Bonatto, F. and Gelain, D. (2007) Oxidative stress in chronic obstructive pulmonary disease patients submitted to a rehabilitation program. Respiratory Medicine, 101, 1830-1835. doi:10.1016/j.rmed.2007.02.004

[31] Mercken, E.M., Calvert, L.D., Singh, S.J., Hageman, G.J., Schols, A.M. and Steiner, M.C. (2009) Dichloroacetate modulates the oxidative stress and inflammatory response to exercise in COPD. Chest, 136, 744-751. doi: $10.1378 /$ chest. $08-2890$

[32] Mercken, E.M., Hageman, G.J., Langen, R.C., Wouters, E.F. and Schols, A.M. (2011) Decreased exercise-induced expression of nuclear factor- $\kappa \mathrm{B}$-regulated genes in muscle of patients with COPD. Chest, 139, 337-346. doi:10.1378/chest.10-0275

[33] Puente-Maestu, L., Lázaro, A., Tejedor, A., Camaño, S., Fuentes, M. and Cuervo, M. (2011) Effects of exercise on mitochondrial DNA content in skeletal muscle of patients with COPD. Thorax, 66, 121-127. doi:10.1136/thx.2010.153031

[34] Graham, T.E., Bangsbo, J., Gollnick, P.D., Juel, C. and Saltin, B. (1990) Ammonia metabolism during intense dynamic exercise and recovery in humans. American Journal of Physiology, 259, E170-E176.

[35] Calvert, L.D., Singh, S.J., Morgan, M.D. and Steiner, M.C. (2011) Exercise induced skeletal muscle metabolic stress is reduced after pulmonary rehabilitation in COPD. Respiratory Medicine, 105, 363-370. doi:10.1016/j.rmed.2010.10.012

[36] Bernard, S., Whittom, F., Leblanc, P., Jobin, J., Belleau, R. and Bérubé, C. (1999) Aerobic and strength training in patients with chronic obstructive pulmonary disease. American Journal of Respiratory and Critical Care Medicine, 159, 896-901.

[37] Maltais, F., Le Blanc, P., Simard, C., Jobin, J., Bérubé, C. and Bruneau, J. (1996) Skeletal muscle adaptation to endurance training in patients with chronic obstructive pulmonary disease. American Journal of Respiratory and Critical Care Medicine, 154, 442-447.

[38] Rochester, C.L. (2003) Exercise training in chronic obstructive pulmonary disease. Journal of Rehabilitation Research and Develop, 40, 59-80. doi:10.1682/JRRD.2003.10.0059

[39] Terrados, N., Jansson, E., Sylvén, C. and Kaijser, L. (1990) Is hypoxia a stimulus for synthesis of oxidative enzymes and myoglobin? Journal of Applied Physiology, 68, 2369-2372.

[40] Garcia-Aymerich, J., Lange, P., Benet, M., Schnohr, P. and Antó, J.M. (2007) Regular physical activity modifies smoking-related lung function decline and reduces risk of chronic obstructive pulmonary disease: A populationbased cohort study. American Journal of Respiratory and Critical Care Medicine, 175, 458-463. doi:10.1164/rccm.200607-896OC

[41] Toledo, A.C., Magalhaes, R.M., Hizume, D.C., Vieira, R.P., Biselli, P.J. and Moriya, H.T. (2012) Aerobic exercise attenuates pulmonary injury induced by exposure to cigarette smoke. European Respiratory Journal, 39, $254-$ 264. doi:10.1183/09031936.00003411

[42] Barreiro, B., Rabinovich, R., Marin-Corral, J., Barberà, J.A., Gea, J. and Roca, J. (2009) Chronic endurance exercise induces quadriceps nitrosative stress in patients with severe COPD. Thorax, 64, 13-19. doi:10.1136/thx.2008.105163

[43] Silva, L.A., Pinho, C.A., Scarabelot, K.S., Fraga, D.B., Volpato, A.M. and Boeck, C.R. (2009) Physical exercise increases mitochondrial function and reduces oxidative damage in skeletal muscle. European Journal of Applied Physiology, 105, 861-867. doi:10.1007/s00421-008-0971-8

[44] Casaburi, M., Patessio, A., Ioli, F., Zanaboni, S., Donner, C.F. and Wasserman, K. (1991) Reductions in exercise lactic acidosis and ventilation as a result of exercise training in patients with obstructive lung disease. The American Review of Respiratory Disease, 143, 9-18.

[45] Rabinovich, R.A., Ardite, E., Mayer, A.M., Polo, M.F., Vilaró, J. and Argilés, J.M. (2006) Training depletes muscle glutathione in patients with chronic obstructive pulmonary disease and low body mass index. Respiration, 73, 757-761. doi:10.1159/000094395

[46] Flück, M. (2005) Hypoxaemia enhanced peripheral muscle oxidative stress in COPD. Thorax, 60, 797-798. doi:10.1136/thx.2005.047738

[47] van Helvoort, H.A., Heijdra, Y.F., Heunks, L.M., Meijer, P.L., Ruitenbeek, W. and Thijs, H.M. (2006) Supplemental oxygen prevents exercise-induced oxidative stress in muscle-wasted patients with chronic obstructive pulmonary disease. American Journal of Respiratory and Critical Care Medicine, 173, 1122-1129. doi:10.1164/rccm.200512-19570C

[48] Tsan, M.F. (2001) Superoxide dismutase and pulmonary oxygen toxicity: Lessons from transgenic and knockout mice. International Journal of Molecular Medicine, 7, 13-19. 
[49] Itoh, M., Oh-Ishi, S., Sudo, A., Hatao, H., Komiyama, M. and Kishi, K. (2005) Effect of pulmonary rehabilitation on endurance capacity and oxidative stress in patients with COPD. Proceedings of the 100th American Thoracic Society, San Diego, 20-25 May 2005, A53.

[50] Nemoto, K., Itoh, M., Nakamura, H. and Oh-Ishi, S. (2012) Effect of exercise therapy on reactive oxygen species and reactive nitrogen species in COPD patients. Journal of Tokyo Medical University, 70, 34-41.

[51] Onur, E., Kabaroğlu, C., Günay, O., Var, A., Yilmaz, O. and Dündar, P. (2011) The beneficial effects of physical exercise on antioxidant status in asthmatic children. Allergol Immunopathol (Madr), 39, 90-95. doi:10.1016/j.aller.2010.04.006

[52] Rammaert, B., Leroy, S., Cavestri, B., Wallaert, B. and
Grosbois, J.M. (2011) Home-based pulmonary rehabilitation in idiopathic pulmonary fibrosis. Revue des Maladies Respiratoires, 28, 52-57. doi:10.1016/i.rmr.2011.06.006

[53] Holland, A.E., Hill, C.J., Conron, M., Munro, P. and McDonald, C.F. (2008) Short term improvement in exercise capacity and symptoms following exercise training in interstitial lung disease. Thorax, 63, 549-554. doi:10.1136/thx.2007.088070

[54] Jackson, R., Ramos, C., Gupta, C. and Gomez-Marin, O. (2010) Exercise decreases plasma antioxidant capacity and increases urinary isoprostanes of IPF patients. Respiratory Medicine, 104, 1919-1928. doi:10.1016/j.rmed.2010.07.021 